\section{The threat to peer review}

Colin Norman reports from Washington on a series of events which provides $a$ vivid example of the difficulties sometimes encountered by scientists engaged in research on controversial topics

IN A move believed to be without direct precedent, the House of Representatives on April 13 voted to shut off funds for a scientific research project because a powerful Congressman believes the project is scientifically unsound and morally unacceptable. A number of scientists have charged that the vote, if upheld in the Senate, constitutes a worrying challenge to academic freedom.

The project is certainly controversial. An attempt to determine the effects, if any, of marijuana on human sexual responses, it attracted considerable press attention when it was approved last year, and it has stirred up various expressions of moral outrage. Nevertheless, the research has been judged scientifically meritorious by committees of scientists expert in the field, endorsed by the federal government's top advisory committee on drug abuse, and been subjected to a searching inquiry by the government's senior health officials. If Congress does abort the project, the move is certain to be interpreted in the scientific community as political interference with the painstaking peer review process used by virtually every government agency to determine the relative merits of research proposals.

The project is a two-year research effort to be conducted by Dr Harris Rubin, a behavioural scientist at Southern Illinois University Medical School, Carbondale. Rubin's research protocol notes that though there have been many verbal and subjective reports indicating that marijuana has a substantial effect on human sexual behaviour, those effects and the drug's mode of action have not been objectively evaluated. His project involves giving measured doses of marijuana to volunteers and then measuring their physical responses to visual stimuli such as erotic films. Part of the expriment also involves monitoring blood levels of various sex hormones, such as testosterone.

Rubin applied for a grant from NIH for his project in May 1974, and his application was passed on to the National Institute on Drug Abuse (NIDA). It was reviewed for scientific merit by a peer review committee in the usual manner, and two well known behavioural scientists - Dr Joseph Brady of Johns Hopkins University and Dr Jonathan Cole of Columbia University-conducted a site visit and discussed the application with Rubin in January 1975 , The peer review committee subsequently approved the project as being scientifically valid, and NIDA decided to fund it in June 1975 with a grant of about $\$ 121,000$ over two years.

It was then that Rubin's troubles began. A routine announcement of the grant by Southern Illinois University was picked up by the press, several accounts of the pri iect were published, and it was attacked in the St Louis Globe Democrat as "tax-paid debauchery". Then Senator William Proxmire, the colourful Senator from Wisconsin who has frequently denounced soientific research which he considers trivial or unsound, took the project in his sights and fired off a press release calling it "one of the most shocking examples of the "federal love machine' I have ever found". That attracted considerable attention from the media.

While that furore was beginning to break, Rubin applied to the Department of Justice for a grant of immunity from federal prosecution, normally a routine procedure for scientists conducting approved studies with illicit drugs. The application turned out to be far from routine, however, for the Justice department sat on his application for six months, and in January this year it asked the Secretary of the Department of Health, Education and Welfare (of which NIDA is a part) to reevaluate the project and determine whether Rubin is suitably qualified to conduct the research. According to HEW officials, the Justice Department's action is unprecedented.

The reevaluation was carried out on March 11 at a closed meeting attended by the head of the Food and Drug Administration, the Assistant Secretary for Health, the head of NIDA, other government officials and a number of outside scientists-probably the most high-powered committee ever to consider a single grant application. According to HEW sources, the meeting resulted in a recommendation to David Matthews, Secretary of HEW, that the project continue to be supported. Matthews has not yet acted on the recommendation. Similarly, on February 11, the NIDA National Advisory Council, a committee composed of scientists and lay members, unanimously passed a resolution urging
Secretary Matthews to support the project.

Rubin has received nearly half of the grant from NIDA, but his project is in limbo until he receives his grant of immunity from the $\mathrm{Justice}$ Department.

Meanwhile, Congress entered the picture largely through the work of Representative Robert Michel, the House Republican Whip, who represents Peoria, Illinois. Michel, a powerful member of Congress, is the most senior Republican on the appropriations subcommittee which handles HEW's budget. $\mathrm{He}$ has denounced Rubin's project on several occasions, calling it "offensive to the sensibilities of most Americans", and he has twice quizzed HEW officials about it.

Michel made his decisive move against the project by writing into a supplemental appropriations bill containing funds for a number of different agencies, a provision cutting off support for Rubin's research. The bill was passed by the House on April 13 with scarcely anybody noticing Michel's handiwork. The bill is now being considered in the Senate, and a number of scientists have already written to their Senators to ensure that the provision doesn't slip past that body unnoticed.

Though there may indeed be questions about the utility of Rubin's research proposal, the fact is that the project has been endorsed by Rubin's scientific peers, and it has been approved after a painstaking review procedure which is a basic ingredient of federal support for science. If Congress were to overturn the funding decision, it would be an unprecedented step. Dr Joseph Brady, one of the chief reviewers of the project, last week called the House vote "outrageous", and pointed out that the review procedure "was a model of the way the peer review system should and can work".

Dr Robert DuPont, the head of NIDA, noted in a telephone interview last week that "Congress has the perfect right to assert itself in terms of how federal money is spent", but he added that "if Congress is going to reverse the considered judgment of the peer review process, I think it should be extremely cautious about setting a precedent".

As for Rubin, he said that he is "very disappointed" by the House vote, and he argued in a letter sent to several of his colleagues that if the Senate follows suit, "the Congress will be overruling the peer review process and politicians rather than scientists will be determining what specific research proiects will be conducted ... the danger to scientific and academic freedom in this precedent is enormous". 